\title{
The Rise (and Fall) of Elected Sheriffs
}

\author{
Cameron DeHart*
}

March 17, 2020

\begin{abstract}
Voters in almost every state elect county sheriffs but political science has only recently turned its attention to this important office. In this paper, I trace the historical processes that led Americans to begin electing sheriffs in the 18th and 19th centuries, as well as modern reforms to reverse that trend. Pairing newly-collected data on the timing of reforms that democratized local offices with narrative history, I show that the institution of elected sheriff spread gradually across the country and, in many states, Americans were deeply conflicted about subjecting this important office to popular choice. One finding is that sheriffs, in most states, became elective sooner than prosecutors and judges. I also provide evidence of the institution's slow retrenchment: today, there are four states and thirteen counties, home to over 20 million Americans, that do not elect sheriffs. The paper concludes with a discussion about the national importance of this local institution in American politics.
\end{abstract}

Keywords: State and local politics; elections; accountability; law enforcement; criminal justice; American political development

${ }^{*} \mathrm{PhD}$ Candidate, Department of Political Science at Stanford University (cdehart@stanford.edu, https://www.camerondehart.com) 
"Since our founding, the independently elected Sheriff has been seen as the people's protector, who keeps law enforcement close to and amenable to the people. The Sheriff is a critical part of the Anglo-American heritage of law enforcement."

Attorney General Jeff Sessions in address to the National Sheriffs' Association (Feb. 12, 2018)

\section{Introduction}

Over 3,000 county sheriffs hold office in the United States and 99 percent are directly elected by voters. Sheriffs operate law enforcement departments in the vast majority of counties, employ $25 \%$ of full-time sworn officers, and oversee $85 \%$ of local jails (Brooks 2019, Reaves and Hickman 1998). State constitutions and local laws grant sheriffs wide-ranging discretion to set law enforcement priorities, and sheriffs today are important actors in a number of policy arenas, including gun control, immigration, and public health (Brown 1978, Falcone and Wells 1995, Farris and Holman 2015, Farris and Holman 2017, Thompson 2020a). At the same time, there is an ongoing debate about monitoring the behavior of sheriffs and other police. Incumbent sheriffs are infrequently challenged at the ballot box and win reelection at high rates (Zoorob 2019a), and there is growing concern that sheriffs' elections do not deliver accountability (Neauhauser 2016, Magary 2018, Tomberlin 2018). Examples of sheriffs misbehaving in office, before ${ }^{1}$ and after $^{2}$ elections, are abundant, and lead many Americans to wonder about the origins and persistence of this institution.

Defenders of sheriffs' elections argue that the practice is consistent with, perhaps inseparable from, the nation's founding principles. For example, when Attorney General Jeff Sessions linked elected sheriffs to "Anglo-American heritage" before the National Sheriff's Association, his critics derided the racial undertones of the term "Anglo" (Gurman 2018, Kopel 2018, Mondschein 2018, Frum 2018). The critics failed to interrogate his assertion that the office of elected sheriff was a unifying feature of the English and American experiences, as well as the implication that voters possess an inherent right to elect their sheriffs.

\footnotetext{
${ }^{1}$ Powers (2018), "The Renegade Sheriffs".

${ }^{2}$ Sheets (2019), "Wasted Funds, Destroyed Property: How Sheriffs Undermined Their Successors After Losing Reelection".
} 
This favored talking point of the National Sheriff's Association ${ }^{3}$, and its state affiliates, goes unchallenged in U.S. politics, the media, and academia (c.f. Neuhauser 2016, Magary 2018).

To inform the debate about sheriffs' elections and accountability, and to evaluate the claims made by county sheriffs and their allies, I provide the first account of how the elected office of sheriff developed and spread in the early United States. In this paper, I show that the truth about the origins and spread of elected sheriffs is more complicated than Sessions suggests. Drawing on newly-collected data on state-level reforms, I trace the paths taken by 18 th and 19th centuries state legislatures and constitutional conventions to explain how Americans transitioned from appointed to elected sheriffs.

States adopted elected sheriffs at different times, between 1706 and 1878, and I argue the asynchronous timing of electing sheriffs was a function of state-level differences in elite competition, state capacity, and party development. Sheriffs were at the center of the antebellum system of "courts and parties" ${ }^{4}$ invested with the power to enforce state laws and court orders. The underlying reasons for adopting elected sheriffs was a principal-agent problem that political elites faced when the need to fill public offices was frustrated by the executive branch's patronage excesses. Reformers before and after independence wanted to remove the sheriff, an important court officer with growing executive power, from the grasp of governors and legislatures - a goal they had largely accomplished before the dawn of the Civil War.

To place my findings about the onset of sheriffs' elections into a proper context, I benchmark the timing of elected sheriffs with the onset of elected prosecutors and judges. I find that, in several states, the move to elect sheriff predated the movement to elect other state and local offices in the Jacksonian Era. In a later section, I present evidence of a slow retrenchment of elected sheriffs in a handful of communities, where voters abolished the institution in the last century. The paper concludes with a discussion about the place of elected sheriffs in 21st century American politics.

\footnotetext{
${ }^{3}$ National Sheriffs' Association resolutions in 2016, 2017, and 2019

${ }^{4}$ The phrase "courts and parties" is from Skowronek (2000), Building a New American State.
} 


\section{Literature}

\subsection{Political science on sheriffs}

Despite their ubiquity and longevity in American society, sheriffs do not appear often in the political science literature. Scholars of southern politics noted that sheriffs held sway in local matters (Key 1949), but the political science research focused on sheriffs was limited to the office's value in local party machine politics (Moley 1929) and the effects of sheriffs' leadership style on their department's bureaucratic organization (Henderson 1975). Today, the literature on county sheriffs is small but growing. Recent work examines the relationship between county sheriffs' attitudes and their departments' policies related to domestic violence (Farris and Holman 2015) and immigration enforcement (Farris and Holman 2017). Other work shows that sheriffs' political attitudes can raise or lower the perceived cost of political violence in their communities (Nemerever 2019)

This research joins the growing literature on sheriffs' elections. Preliminary research suggests that sheriffs enjoy a large incumbency advantage in elections, and serve longer tenures in office relative to appointed police chiefs (Zoorob 2019a). At the same time, sheriffs are highly visible in state and local politics, with increasing relevance in national politics. Progressive candidates for sheriff in 2018 experienced a bump when the incumbent in the race was associated with federal immigration enforcement (Zoorob 2019b). On the other hand, despite polarization over law enforcement issues at the national level, recent research shows that Republican and Democratic sheriffs chosen in close elections are nearly indistinguishable when it comes to their enforcement behavior (Thompson 2020a).

This work joins the research on the effect of elections versus appointment on government performance, including comparisons between electing and appointing judges, prosecutors, election administrators, city treasurers, regulators, and school officials (Huber and Gordon 2004, Bandyopadhyay and McCannon 2014, Kimball and Kropf 2006, Whalley 2013, Besley and Coate 2003, Sances 2016, Partridge and Sass 2011). The findings are mixed with re- 
spect to the impact of elections on policy and performance, but the growing interest in research questions about local elected officials, many of which are unique to the United States, suggests that we need to better understand the historical motivations for adopting these institutions and their persistence over time.

\subsection{The politics of law enforcement}

Research on county sheriffs, today and in the past, benefits from and contributes to the growing literature on the politics of law enforcement and criminal justice. Sheriffs employ $25 \%$ of full-time sworn officers and operate $85 \%$ of jails in the United States (Brooks 2019, Reaves and Hickman 1998), as well as provide many civic and administrative services, meaning that Americans in most states are likely to encounter sheriffs or their employees in the course of their lives. Recent research on the social consequences of contact with law enforcement shows that citizen-police interactions can have an impact on citizens' political attitudes and behavior. Scholars have found that contact with law enforcement and other agents of the carceral state can negatively affect the contactee's trust in government and decrease their likelihood of participating in politics in the future (Lerman and Weaver 2014, White 2019).

In light of this recent research, and this paper's finding that transitions to sheriff elections were deliberate political choices, we should think critically about how elections shape the incentives and behavior of elected sheriffs today. As I show in a later section, Americans in the colonial period and early Republic harbored similar concerns about government officers abusing their power, and they debated about which institutions would hold sheriffs accountable. Americans in the 20th and 21st centuries had similar debates about whether to continue electing their sheriffs in the face of modernization, joining countries around the world trying to hold police accountable without direct elections (Bayley and Stenning 2017, Tomberlin 2018). 


\section{Background}

The popular image of the county sheriff is largely tied to Hollywood portrayals of Old West gunslingers and corrupt Southern enforcers, such that many Americans might think of the office as a vestige of the past. On the other hand, sheriffs' offices today are nearly indistinguishable from any other police department that Americans encounter on a daily basis. The reality is that the office of county sheriff is old, but alive in the United States.

Confining sheriffs to the same class as "the police" belies the complexity of local law enforcement, especially the institutional differences in leadership selection. Many state and local law enforcement agencies are led by appointed or professional bureaucrats and may provide policing and criminal investigation services, but typically do not administer court security and corrections. In addition to being elected in most jurisdictions, sheriffs' offices have a wide range of powers and responsibilities. The laws governing sheriffs vary from state to state, but sheriffs typically play an important role in the criminal justice and/or civil administrative systems in the 46 states where they are elected.

County sheriffs can be legally responsible for any combination of the following duties, depending on the state: police services such as traffic patrols and criminal investigations, security and administrative services for the court system, operating the county jail and juvenile detention facilities, collecting taxes and fees for public services, issuing firearms permits and performing background checks, executing arrest warrants and other civil writs, and taking possession of and reselling private property through foreclosure sales. ${ }^{5}$ Several of the legal responsibilities given to county sheriffs put the office at the center of important policy debates, especially policies pertaining to enforcement priorities, arrests, and detentions. Notable examples of recent sheriff policy controversies include compliance with federal immigration

\footnotetext{
${ }^{5}$ Previous researchers have designated at least four categories of sheriff's offices based on these legal duties and powers: full-service, law enforcement, civil-judicial, and correctional-judicial (Brown 1978, Falcone and Wells 1995). Full-service sheriff's offices exist in $80 \%$ of states and perform criminal, civil, judicial, and correctional duties. The second most common type, civil-judicial, is primarily found in New England: Delaware, New Hampshire, and Vermont. Sheriffs in Massachusetts and New Jersey oversee local jails as well, but do not focus on criminal investigations.
} 
detention requests (Thompson 2020a, Chand 2019), civil asset forfeitures (Nelson 2017), gun permits and gun control (Salonga 2019, Goldstein 2019, Mascia 2020), and sending aid to suppress anti-pipeline protests (Monet 2016).

\subsection{The uniqueness of elected sheriffs}

County sheriffs are exceptional in several ways: police leaders at the federal, state, and municipal level are not usually elected like sheriffs, and with few exceptions, other democracies do not choose their local law enforcement leaders through direct elections. ${ }^{6}$ Furthermore, no other country with sheriffs today, including the United Kingdom and her former colonies, fills the office at the ballot box.

The United States is unique for the large number of public offices that are filled by election rather than appointment or civil service hiring. Besides sheriffs, scholars have looked into the effects of direct elections for local offices on various outcomes, including elected prosecutors and judges, as well as the origin of the institutions themselves (Ellis 2011, Shugerman 2010). Unlike sheriffs, elected prosecutors and judges did not have predecessors in English history, and developed organically stateside within a few generations of independence.

The practice of electing sheriffs began in the Anglo-Saxon period as a privilege extended by the monarch on a shire-by-shire basis, usually for an annual fee (Morris 1927). Otherwise English sheriffs in the medieval and early modern period were appointed by the Crown. The historical practice of electing sheriffs in medieval England was short-lived and largely discontinued by the time the English exported the county system overseas (Gorski 2003, Carpenter 1976). Today, two ceremonial High Sheriffs of London are still elected by the Liverymen, representatives of the city's guilds (De Krey 1983, Kopel 2014).

Non-American sheriffs today fulfill a largely ceremonial role in the several countries that

\footnotetext{
${ }^{6}$ The notable exception is found in England and Wales: Police and Crime Commissioners (Thompson 2020b). As of 2012, 41 Police and Crime Commissioners are elected for four-year terms to oversee police activity within their jurisdiction. Although commissioners are responsible for developing a plan for addressing crime and ensuring public safety, Police and Crime Commissioners do not operate jails, manage deputy officers, or carry out court orders like sheriffs in the United States.
} 
retain them including England, Wales, Scotland, Northern Ireland, and the Republic of Ireland, as well as several countries colonized by the British including Australia, Canada, India, and South Africa. The United States is the only country among these that continues to elect its sheriffs. ${ }^{7}$

There are other examples of elected law enforcement officials, including constables and marshals, but these offices are less widespread than county sheriffs. Constables and marshals operate much like police chiefs within smaller jurisdictions, such as county precincts and townships, and their legal responsibilities are usually limited to patrolling local areas and serving warrants. With little supervision between elections, constables in Pennsylvania and Texas, in particular, are often accused of corruption and abuse of power (San Antonio Express-News 2019, Signorini 2019). Berry \& Gersen (2009) calculate that 701 local police chiefs are elected in 358 counties in the United States, as of 1992 (U.S. Census 1992). Most of the communities that directly elect their police chiefs are found in Louisiana, but communities in other states follow the practice as well. ${ }^{8}$

Two other local offices in the early American period have captured similar scholarly attention, elected prosecutors and judges, and will serve as a benchmark for the development of elected sheriffs. These offices, along with the county sheriff, comprised the key institutions of government in the colonial and early republican period, when the central state had low

\footnotetext{
${ }^{7}$ Sheriffs in England, Northern Ireland, and Wales are ceremonial offices appointed each year by the Crown through the Privy Council, or another noble (e.g. the Duke of Cornwall appoints the High Sheriff of Cornwall). Historically, sheriffs in Scotland were hereditary offices and were akin to judicial officials. The six current 'sheriffs principal' are appointed by the Monarch of the United Kingdom, on the recommendation of the First Minister of Scotland and the Judicial Appointments Board. Four sheriffs in Ireland are appointed by the Minister of Justice to enforce court orders, count election returns, and collect taxes and public debts. Twelve more "revenue sheriffs" are appointed through the civil service to collect taxes and confiscate property on behalf of the revenue agency. County sheriffs in Canada are appointed by each province's lieutenant governor to execute court orders and, in some regions, provide courthouse security. Sheriffs in Australia are appointed by the Chief Justice of the Supreme Court to provide court security and enforce writs, although their responsibilities vary by state and territory. In India, two sheriffs are appointed annually by the state's chief minister in Mumbai and Kolkata, where local celebrities tend to hold the ceremonial office. Sheriffs are appointed by the justice minister in South Africa to execute court orders.

${ }^{8}$ For example, voters in Santa Clara, California elect the city's police chief every four years. Recent elections have been embroiled by controversy over the use of police resources at the newly-built NFL Levi's Stadium, following the San Francisco 49ers' then-quarterback Colin Kaepernick's protests against police brutality (Wilson 2016).
} 
capacity and daily politics centered around the actions of provincial government agents and the court system (Ellis 2011, Shugerman 2010, Nelson 1993). In a later section, I use these timing of reforms to elect these offices to contextualize the historical movement toward elected sheriffs. In the next section, I present newly-collected data on the order states took in adopting elected sheriffs.

\section{Trends in the adoption of elected sheriffs}

Attorney General Jeff Sessions' comments to the National Sheriffs' Association echoed claims made repeatedly by the organization itself that the elected office of sheriff is deeply-rooted in American political tradition, a claim repeated by dozens of state sheriffs' associations. The National Sheriffs' Association's claim that the "ongoing election of the Office of Sheriff...is consistent with our nation's democratic history, traditions, and historical practices" is accurate, but it belies the nuance of that development (Scott 2011). ${ }^{9}$

The popular story about the origins of elected sheriffs is often murky, but always drawing a thread from today's practice to the nation's founders. Sessions' comments link the modern sheriff to the medieval English gentry who selected a sheriff amongst themselves to host the King's representatives during royal visits to the shire. Other sheriff boosters point to an aftquoted 1816 letter from Thomas Jefferson (1816), in which the former president advocates for electing sheriffs. ${ }^{10}$ If Jefferson's call was not answered in every state by the time of his death in 1826, perhaps the Jacksonian impulse for populist reform that soon followed shepherded the spread of elected sheriffs.

The truth is more nuanced, as Table 1 shows. A handful of states began electing their sheriffs at independence, or when they first declared statehood, around 1776. These included Pennsylvania and Delaware, as well as New Jersey, Maryland, North Carolina, and Georgia.

\footnotetext{
${ }^{9}$ See the resolutions passed by the National Sheriffs' Association Board of Directors in 2016, 2017, and 2019.

${ }^{10}$ Jefferson (July 12, 1816), "Letter to Samuel Kercheval." If American voters (especially Virginians) were denied the opportunity to elect their sheriffs, Jefferson asked, "Where then is our republicanism to be found?"
} 
Table 1: The Adoption of Elected Sheriffs in the United States

\begin{tabular}{|c|c|c|c|}
\hline State & $\begin{array}{c}\text { Year of } \\
\text { Statehood }\end{array}$ & $\begin{array}{c}\text { Year } \\
\text { Sheriffs Elected }\end{array}$ & $\begin{array}{l}\text { Method of } \\
\text { Reform }\end{array}$ \\
\hline Pennsylvania & 1776 & 1706 & Colonial Charter \\
\hline Delaware & 1776 & 1706 & Colonial Charter \\
\hline New Jersey & 1776 & 1776 & Constitution \\
\hline Maryland & 1776 & 1776 & Constitution \\
\hline North Carolina & 1776 & 1776 & Constitution \\
\hline Georgia & 1776 & 1777 & Statute \\
\hline Kentucky & 1792 & 1792 & Constitution \\
\hline Vermont & 1793 & 1793 & Constitution \\
\hline Ohio & 1802 & 1802 & Constitution \\
\hline South Carolina & 1776 & $1808^{\dagger}$ & Statute \\
\hline Indiana & 1816 & 1816 & Constitution \\
\hline Mississippi & 1817 & 1817 & Constitution \\
\hline Illinois & 1818 & 1818 & Constitution \\
\hline Alabama & 1819 & 1819 & Constitution \\
\hline Missouri & 1821 & 1821 & Constitution \\
\hline New York & 1776 & $1821^{\dagger}$ & Constitution \\
\hline Arkansas & 1836 & 1829 & Territory \\
\hline Michigan & 1837 & 1835 & Territory \\
\hline Tennessee & 1796 & $1835^{\dagger}$ & Constitution \\
\hline Connecticut & 1776 & $1838^{\dagger}$ & Const. Amendment \\
\hline Florida & 1845 & 1845 & Statute \\
\hline Louisiana & 1812 & $1845^{\dagger}$ & Constitution \\
\hline Texas & 1845 & 1845 & Constitution \\
\hline Iowa & 1846 & 1846 & Constitution \\
\hline Wisconsin & 1848 & 1848 & Constitution \\
\hline California & 1850 & 1850 & Constitution \\
\hline New Mexico & 1912 & 1850 & Territory \\
\hline Minnesota & 1858 & 1851 & Constitution \\
\hline Virginia & 1776 & $1851^{\dagger}$ & Constitution \\
\hline Utah & 1896 & 1854 & Territory \\
\hline Massachusetts & 1776 & $1855^{\dagger}$ & Const. Amendment \\
\hline Maine & 1820 & $1855^{\dagger}$ & Const. Amendment \\
\hline Nebraska & 1867 & 1855 & Territory \\
\hline Oregon & 1859 & 1859 & Constitution \\
\hline Colorado & 1876 & 1861 & Territory \\
\hline Kansas & 1861 & 1861 & Constitution \\
\hline West Virginia & 1861 & 1863 & Constitution \\
\hline Nevada & 1864 & 1864 & Constitution \\
\hline Arizona & 1912 & 1865 & Territory \\
\hline Montana & 1889 & 1872 & Territory \\
\hline New Hampshire & 1776 & $1878^{\dagger}$ & Statute \\
\hline Wyoming & 1890 & 1879 & Territory \\
\hline North Dakota & 1889 & 1889 & Constitution \\
\hline South Dakota & 1889 & 1889 & Constitution \\
\hline Washington & 1889 & 1889 & Constitution \\
\hline Idaho & 1890 & 1890 & Constitution \\
\hline Oklahoma & 1907 & 1890 & Territory \\
\hline Rhode Island & 1776 & n.d. & - \\
\hline Alaska & 1959 & n.d. & - \\
\hline Hawaii & 1959 & n.d. & - \\
\hline
\end{tabular}

States are ordered by the year in which they adopted direct elections for county sheriffs. The original thirteen colonies are in bold. ${ }^{\dagger}$ denotes states that adopted sheriff elections after statehood (9). 
More than half of the colonies, however, would not begin electing sheriffs until several decades after independence. One state, Rhode Island, would never join the rest of the country in electing sheriffs. These data shed light on the folk myths about sheriffs and provide historical context to inform public knowledge about the origins of our political system.

In order to identify the dates when sheriffs became elected in each state, I used a multipronged strategy to search historical documents for the earliest references to the practice. For each state, I searched the first state constitution (including the amendments) for provisions related to electing sheriffs (or all county officers). If there is no such provision in the first constitution, I move on to that state's second constitution and so on. If the provision for electing sheriffs is not found in a state's constitution or constitutional amendments, I next search digitized copies of the state's laws, codes, and statutes for the earliest reference to elected sheriffs. ${ }^{11}$ For each of the thirteen colonies, if the first state constitution includes a provision for elected sheriffs, I search every charter that governed the colony before 1776, in reverse sequential order, for the earliest reference to elected sheriffs. Table 1 presents the states in the order in which they adopted elected sheriffs. For each state, I present the year in which sheriff elections were first authorized, the year of statehood, and the method by which states adopted the institution (e.g. in the state constitution or a constitutional amendment, by statute passed by the state legislature, or in territorial governing documents).

What was the early political environment like for these new American sheriffs? Early governments, at the federal and state level, lacked well-defined coercive powers and had no standing army; the decentralization of militias in the states limited the president's capacity to collect taxes or maintain public safety. The early American national state was weak compared to the strong executive systems in Europe, and the police power in the early nation was exercised at the local level, with the courts and sheriffs at the center of local administration.

\footnotetext{
${ }^{11}$ Many states existed as territories before being admitted to the Union, and several territories were subdivided into counties and elected their own sheriffs before statehood. In this paper, I present only the date of statehood to denote the start of sheriffs elections.
} 
Within the tripartite separation of powers, the courts were more powerful than the legislature, which focused on minor public works and private business, and the presidency, which was similarly slow to develop institutional capacity. Scholars of American political development have noted the weakness of the federal state, calling the early American system a "state of courts and parties" (Skowronek 2000), and sheriffs played a central role within the local court system (Key 1949, Moore 1997, Mickey 2015). In the next section, I examine the colonial origins of the sheriff's power, wherein we find the roots of elected sheriffs being planted in the United States.

\section{The colonial context: sheriffs in early America}

County sheriffs, like many institutions in American politics, are a remnant of the English legal system that the American states inherited in the colonial period. Sheriffs were transplanted in North America from England, where the office served for several hundred years as agents of the Crown. The English experience with sheriffs over the millennia of the office's existence was characterized by principal-agent problems.

English sheriffs in the medieval period were appointed by the monarch from among the lesser landed gentry of the shire. The ideal candidates were said to be individuals with sufficient wealth to represent the Crown faithfully before his community, so he could not only host lavish dinners in the king's name, but to be sure he enjoyed financial independence without expropriating funds from his neighbors, or the tax monies destined for the king's pocket (Gorski 2003). Nonetheless, royal sheriffs were often accused of coercive behavior and abuse such as extracting large fees from locals and confiscating property on the Crown's behalf. Magna Carta specifically targeted the sheriffs for their abusive execution of Crown rule: "We will appoint as...sheriffs...only men that know the law of the realm and are minded to keep it well." 12

\footnotetext{
${ }^{12}$ Clause 45, Magna Carta (1215). See also Clause 30: "No sheriff, royal official, or other person shall take horses or carts for transport from any free man, without his consent."
} 
Sheriff's offices in England and the colonies were rife for abuse given their involvement in tax and duty collection, but their reputation also stemmed from the sheriffs' role as an officer of the Crown, the most proximate of the King's agents sent to enforce unpopular laws as necessary. Given the experience with abusive sheriffs through the medieval period, the landed elite sought constraints on the Crown and its officers through Parliament, the judicial system, and the Exchequer. Over several centuries, Parliament placed sheriffs under the courts' control and stripped them of their executive powers, which were dispersed to other offices like coroner and justices of the peace. By the time the first sheriffs were appointed in North America in the 17th century, the sheriff's office held minimal value as a patronage appointment: ceremonial pomp and prestige were the whole of shrievalty's reward in England (Gorski 2003, Kopel 2014).

Sheriffs were first appointed in North American in 1634 in Virginia, selected initially by governor, and later nominated by the county courts with final approval by the colonial assembly. The English divided the land into shires, renamed counties in 1642, to administer colonial rule and provide structure for the development of new settlements. Among the colonists' most proximate concerns were public safety and defense. Sheriffs replaced a rotating cast of martial officers, including provost marshals, militia commanders, and night watchmen, who administered the jail, arrested outlaws, and provided defense against Native American raids.

Before the introduction of county elections, colonial sheriffs were chosen in two general ways. In New England and the mid-Atlantic colonies, sheriffs were appointed by the governor or general assembly. Southern sheriffs were appointed by the local justices of the peace, who were themselves subject to the final approval of the colonial legislature. Given the office's historical infamy, and the burdensome work of traveling around the colony at their own expense, few colonists were enthusiastic about being appointed sheriff.

The necessities of colonial administration, however, drove the Americans to revest their sheriffs with executive power. By 1676, the colonial government of Virginia reversed the 
English trend of county sheriffs wilting under judicial control. Expense and practicality prevented the English from sending armies of Treasury officials and tax collectors to the colonies, so it fell upon the sheriffs once again to collect public monies on the Crown's behalf. Within a generation or two of English settlement, the colonial assemblies began to allow sheriffs to skim fees from the taxes they collected from colonists, as an inducement for people to take the otherwise low-prestige, if not outright reviled, office. As tax revenue increased in the colonies, along with the workload of local courts, sheriffs took on an increasingly vital role in local administration (Boyd 1928). Consequently, sheriffs' offices became an attractive target for rent-seeking individuals, and a valuable asset in the government's patronage portfolio.

Pennsylvania was by far the most liberal among the original colonies: reformers there introduced local elections and open suffrage for white men early on. The Pennsylvania Frame of Government in 1682 called for the colonial assembly to appoint county sheriffs. In 1701, Pennsylvania counties were allowed to submit a list of two nominees for sheriff and coroner, from which the governor would commission one candidate for each office. Dual nomination soon evolved into elections: just five years later, the county voters were directly selecting their own sheriffs. Delaware adopted elected sheriffs at the same time, being governed under Pennsylvania's frame of government as the so-called "Lower Counties".

The introduction of elective sheriffs in Pennsylvania and Delaware, interestingly, predated the major conflicts over patronage appointments between the rising local elite class, on the one side, and the Proprietors and Governor, on the other. The Penn family held several offices in patronage, and the colonial legislature steadily chipped away at their portfolio of appointments. Sheriff elections were retained in the Pennsylvania Constitution in 1776, and spread along the coast as Maryland, Delaware and New Jersey copied the document for their own purposes. Convention records from that period show that reformers adopted sheriffs' elections with little debate.

New Jersey, which was governed much like its neighbors, notably lacked competitive partisan politics, as the landed elite who dominated local government and the legislature 
agreed on basic questions about government structure. In Maryland, the sheriff was one of the governor's many patronage positions, and the legislature fought to institute constraints on the behavior of the governor's agents. Constraints like term limits and minimum propertyholding requirements allowed the assembly to exercise a modicum of control over appointed sheriffs, in parallel with other reforms that separated power over the colonial budget in the lead up to the revolution. ${ }^{13}$ Thus, the tradition of electing sheriffs was one of several features in modern American politics that can be traced to colonists' mistrust of unchecked executive power.

In New England, the 1691 Massachusetts charter allowed the royal governor to appoint sheriffs, a practice that continued in both Massachusetts and Maine until 1855. Similar institutional arrangements existed in New Hampshire and Rhode Island, and persisted until 1878 and the present day, respectively. Connecticut did not adopt a new constitution upon independence, and continued appointing sheriffs until a constitutional amendment was adopted in 1838 .

Unlike New England and the Atlantic states, where central appointment gave way to local elections, county sheriffs were selected by local politicians in many Southern states before the American Revolution. In the absence of strong central governments, the politics in colonies like Virginia and North Carolina were ruled by strong local county courts. The Justices of the Peace, who were themselves elected by local landowners or appointed by elites in the colonial assembly, were responsible for appointing the sheriffs. These states lacked strong governors to appoint government agents to far-flung and sparsely populated counties where local elites held sway. In most Southern states except Virginia, where the landed elite held tight control over county courts, sheriffs became elective soon after Independence.

Southern elites did not distribute patronage through the colonial and state governments

\footnotetext{
${ }^{13} \mathrm{My}$ argument is consistent with the development of other institutional arrangements that separated power in the colonial period (Gailmard 2017, Gailmard 2019). For example, colonial legislatures could constrain the governor's appointment power by implementing term limits for sheriffs. Such limits prevented the governor from growing his patronage portfolio, but the limited time in office also hindered opportunities for those offices to development into professional agencies.
} 
to the same degree as elites in New England and Atlantic states, in part because the colonial government had not been thoroughly centralized and developed. The county courts, populated by the same landed elite that held sway in the legislature, were governed by the justices of the peace, who joined sheriffs, coroners, and other smaller offices to form the whole of local administration. These offices were nominally elective, but property-holding qualifications for voting and holding office gave the landed gentry firm control over local government and patronage appointments (Corvalan et al 2016).

Despite the increase in local influence over sheriff appointments, stories about abusive royal sheriffs abounded in the South, especially in regions where new white settlers and the ruling elite had divergent interests. For example, the royal sheriffs in North Carolina invoked frequent complaints from colonists, including numerous statutes in the legislature to rein in the sheriffs' abusive behavior. The Regulator movement in North Carolina resisted colonial sheriffs with violence, refusing to pay royal taxes and forcing the Crown's agents out of the western counties (Watson 1976, Watson 1978, Boyd 1928).

\section{After independence: Parties, patronage, and state development}

In this section, I discuss that factors that contributed to the United States adopting elected sheriffs in the period up to the Civil War. The three main factors I will consider are the development of political parties, central state capacity, and the importance of patronage appointments in each state. Four states joined Pennsylvania and Delaware to adopt elected sheriffs at independence: Georgia, Maryland, New Jersey, and North Carolina. Six of the original thirteen colonies made sheriffs elective at some point after independence: South Carolina, New York, Connecticut, Virginia, Massachusetts, and New Hampshire. Rhode Island would never elect sheriffs, and New Hampshire went the longest period of time as a state before adopting elected sheriffs (102 years; 1776 to 1878). 
Conventional wisdom is that the United States experienced two major spurts of liberalization, in the decades following independence, roughly 1776 to 1800, and again during the Jacksonian Era, roughly the mid-1820s to 1850s (Tarr 2000). The belief, even if not articulated with such specificity, is that the spread of sheriff elections was completed in a relatively short window of that latter period. If half the country had adopted elected sheriffs in one fell swoop, so too must have the other states, the logic goes, adopted elected sheriffs in a national craze for Jacksonian democracy. As the timeline in Table 1 reveals, however, that was not the pattern taken by several of the original states. Nor did all newly-admitted states enter the union automatically with elected sheriffs, including Louisiana, Maine, and Tennessee.

A common interpretation of the Jacksonian Era suggests that reformers changed the structure of state and local government between 1828 and 1850 in order to increase the responsiveness of public officers to citizens' interests, by expanding the franchise and increasing the number of directly elected offices. In constitutional conventions, reformers took away the appointment power from governors, legislators, and county courts, and vested it in the hands of local voters and the ascendant mass political parties (McCormick 1966, Tarr 2000).

The period in question, the Jacksonian Era, is also known as the Second Party System, characterized by mass political parties working to mobilize voters in increasingly competitive federal, state, and local elections. Patronage appointments, in government as well as the party apparatus, became the currency of the spoils system through which party leaders distributed lesser offices to local elites, who would in turn mobilize voters and volunteers during election season. It is important to note, however, that the rise of popular politics did not follow the same trajectory across the new nation for a number of reasons: across states and regions elections were not equally competitive, the parties were not equally developed, and the institutions of government differed.

It was the interplay between the structure of government, centralized vs localized, the relative importance of patronage in state politics, and the strength of political parties that 
contributed to states adopting elected sheriffs at different times. How do we make sense of this pattern? Why did sheriffs and other county officers become democratically elected in states with developed political parties later than did sheriffs in states with weak party organizations?

One explanation is that politicians are reluctant to reform political institutions unless the electoral benefits of that reform outweigh the costs, i.e. the risk of losing an election. In some circumstances, dominant politicians might favor reforms that hurt their political prospects in the short-term, but preserve them in the long-term. Consider a hypothetical case in which a party enjoyed firm control over statewide offices, and thus held firm control over patronage appointments. In light of social or economic changes that make the opposition party more competitive in statewide elections, the dominant party might see an incentive to lessen the blow to their control over patronage appointments by reforming the appointment system to minimize political control.

\subsection{The case of New York in 1821}

To match the hypothetical to a real case, consider New York. ${ }^{14}$ The Federalist Party was dominant in New York after the War of 1812, but faced impending removal from power as the national party collapsed. The governor and legislature previously controlled patronage at the state level in the first party system, but would lose control of statewide offices in the foreseeable future. The Federalists hoped to maintain nominal control over public offices in their local strongholds, and pushed for county sheriff elections in the constitutional convention to ensure nonzero influence over judicial and financial governance locally. As the Federalist Party approached the point of losing state-wide control, they reformed the institutions to give themselves greater access to power.

In New York, where the Federalists had the strongest incentive and opportunity to carve out patronage access, the party had largely disbanded or integrated into the Democratic-

\footnotetext{
${ }^{14}$ This narrative sketch of New York's reforms from 1800-1822 follows McCormick (1966), as well as consultation with primary source material, including state constitutional convention records.
} 
Republican party. Lingering factions of the old Federalists remained active in their new party, and may have influenced reforms in the 1821 Constitution. The New York constitution drafted in 1777 by John Jay favored a strong executive and firm separation of powers, and the culture of partisan organization was similar to that in New England and Pennsylvania. The governor and a council of legislators shared the appointment power, making state government the focal point of politics, with only minor emphasis on county-level politics as it related to administering state policies and mobilizing partisan efforts up to the state level. Local officers, including the sheriff, were agents of the state and the county was the unit of state administration, not an independent center of political authority (Gilbertson 1917).

The 1801 constitutional convention was called to resolve disputes over the 1777 document, and reformers ultimately preserved the power-sharing agreement. The Constitution created the Council of Appointments, comprised of the Governor and four Senators, to share the power to appoint the several state, county, and city offices, but the aristocratic institution could not long sustain the balance between executive and popular control. The composition of the Council was susceptible to the electoral swings between Federalists and DemocraticRepublicans in the first party system. As the Federalists dropped out of competition by 1817, warring Republican factions contested the governorship. Former Federalists and canal advocates threw their support to DeWitt Clinton, but Clinton faced strong opposition from a faction within the Democratic-Republican party, known as the 'Bucktails'. By 1820, Clinton was flouting his co-partisans on the Council of Appointment and distributing patronage to canal policy loyalists.

The Bucktails called for, and dominated, the 1821 New York constitutional convention, buoyed by their promise to lift the property-owning requirement for white men to vote. The Governor's patronage opportunities were restricted by the new constitution, but political factions disagreed about how public offices should be filled. In a rebuke to Governor Clinton's coalition, the final document disbanded the Council of Appointments and vested the legislature with the power to appoint state officers and judges (McCormick 1966). But the 
Bucktails, led by Martin Van Buren, stopped short of fully endorsing local elections. Radical democrats within the party allied with former Federalists like Rufus King to implement direct elections for some county officers, including the sheriff. Thus, the innovation of elective sheriffs arose from a conflict between factions of the same party over power sharing across institutions, one executive and one representative.

\subsection{New England and the Mid-Atlantic}

To further evaluate our theory about the relationship between parties, patronage, and direct elections, it is helpful to consider which relevant cases are available for comparison. The relevant cases to consider here are those states with competition between political parties by 1824 , the end of the first party system, a set restricted mostly to the New England and Middle states. Government in early New England was focused at the state and town levels, with a notable absence of county politics. With the exception of Vermont (1793), the states in this region were late to adopt elective sheriffs: Connecticut (1838), Massachusetts (1855), New Hampshire (1878), Maine (1855), and Rhode Island (n.d.). Political factions originated in towns and alliances across towns, and competed for statewide office to then fill the intermediate offices such as county sheriff.

Consider Massachusetts, for example, an exemplar of New England state development that inherited a political culture of state-centered contests between town-based factions. In that system, statewide officers appointed local offices, and the major political factions mobilized to control patronage through the central state apparatus. The state, not the county, was the focal point of politics, and sheriffs remained patronage appointees here until the 1850s.

By 1824, only Maine, Massachusetts, New Jersey, Delaware, and Maryland still had competitive elections between Federalists and Republicans, but the presence of local elections varies by state. Sheriffs and other county officers would continue to be appointed by the central government in Maine and Massachusetts until the 1850s, whereas the other three states 
adopted sheriff elections at independence. Conversely, the Federalist party had dissolved in several states by 1824, and state elections became remarkably noncompetitive: Vermont, New Hampshire, Connecticut, Rhode Island, Pennsylvania, Virginia, and North Carolina. In none of these cases did the predicted relationship emerge: Federalists facing an impending surge out of office did not, or could not, implement local elections to preserve their patronage opportunities.

The case of Connecticut in the 1830s exhibits the relationship between party competition and the expansion of local elections. From 1662 to 1818, Connecticut was governed by a colonial constitution that reinforced elite hegemony, low party competition, and low participation. Federalists dominated statewide office until the first state constitution in 1818, when several reforms increased the stakes of statewide elections. Many state and national offices became elected by the state-at-large, and control of local patronage was centralized in a Council of Assistants. By the 1830s, Whigs and Democrats were trading control of the legislature and governorship regularly, and parties developed town-based committees to fill offices. Given these conditions, it is plausible that the state legislature passed a statute to make sheriffs elective in 1838 to create stability in the parties' local control, rather than to reduce the instability of the competitive winner-takes-all system under the centralized Council of Assistants.

\subsection{The South}

If political development in the New England and mid-Atlantic states can be characterized by the strength of political parties and a state-centered politics, then the South and newlyadmitted states are defined by weak party development and emphasis on local decisionmaking. I find that the Southern states were quicker to adopt elected sheriffs after independence than their northern neighbors. Just four southern states did not elect sheriffs at the time of statehood: South Carolina, Virginia, Tennessee, and Louisiana. Georgia and North Carolina began electing sheriffs after 1776-1777, followed by Kentucky adopting the practice 
upon statehood in 1792. South Carolina was the next state among the original colonies to start electing sheriffs, by statute in 1808, around the same time the state assembly dropped the property-owning requirements for white men to vote. Every southern state admitted to the Union after Louisiana entered with elected sheriffs, starting with Mississippi in 1817.

In the South and newly-admitted frontier states, the factors that contributed to the early adoption of sheriff and other county elections were the vastness of the territory, the weak capacity of the state and parties, and the newness of political communities (Tomberlin 2018). These states were frontier zones during the early Jacksonian period, and new settlers to any particular county worked to "make" government for themselves. By allowing citizens to elect their county officers, those states' constitutions surrendered the control of patronage to the emerging local political interests, rather than re-enforce pre-existing cleavages.

Party development was slower in the South, including Virginia, Kentucky, North Carolina, Tennessee, and Georgia. The party machinery was informal and politics was locally-based and driven by personalistic factions. Unlike New England, the state was of secondary concern to political actors. Political life centered around the county courts comprised of justices of the peace drawn from the local landed elite. Factions of local elite, the remnants of the colonial ruling class, held firm control over the local county courts and appointed themselves as sheriffs and clerks. The South designed the least democratic constitutions in the early nation, and the elitism of politics militated against strong parties in Virginia and North Carolina: "A limited franchise, a social structure dominated by recognizable gentry families, an oligarchic local government system, a paucity of elected officials - all these factors rendered complex party organization unnecessary, as did the simplicity of the electoral system" (McCormick p. 181).

Politics in Georgia were bifocal, at the state and county levels, but formal political parties were absent until 1834. In this case, sheriffs were made elective by the 1777 Constitution, and the practice was affirmed by statute in 1811, long before mass political parties developed. In the absence of a dominant elite class and elaborate party machines, Georgia's political 
factions organized around strong personalities and local interests. Local parties developed in each county and allied together semi-regularly to contest legislative elections and secure patronage for their kith and kin. Given the early adoption of elected sheriffs, those office also became an important source of patronage in their own right.

Virginia was a puzzle in the South: why did Old Dominion elect their sheriffs in 1851, more than a generation after its neighbors had done the same? The elite in Virginia were more deeply entrenched than those in the other states, the only one which could not be accurately described as 'sparsely-populated frontier' by 1820. In Tennessee (1838), North Carolina (1776), Kentucky (1792), and Georgia (1777), the size of the district and absence of strong parties explains the early adoption of elective sheriffs. These states were new political communities by the end of the first party system, and experienced large population increases which hampered the development of strong parties. The political establishment was relatively weak here, compared to Virginia, and politics often arose locally around farflung frontier communities of new settlers, many of whom lacked experience with political parties.

As the number of counties proliferated, with no strong state government to speak of, the prospect of centralized patronage appointments was implausible. The county court system was copied in the old Southern states, opening up local offices to competition between personalistic factions, not well-coordinated state parties. Elected offices became focal points for opportunists to rally regional support and fill patronage positions of their own, such as bailiff and deputy. These cases demonstrate that weak state development and weak party development together can coincide with widespread direct democracy at the local level.

It is clear, however, that sheriffs played an increasingly important role in the development of Southern politics. As the sole law enforcement officer in most counties in the South, sheriffs played an invaluable role in maintaining the authoritarian political system that came to define the region from the 19th century to the 1960s (Mickey 2015, Moore 1997). Specifically, as the overseers of county jails throughout the South, sheriffs routinely led posses to capture 
fugitive slaves before the Civil War, and were later instrumental in perpetuating the convict leasing system that resulted in the re-enslavement of thousands of African-Americans after the Civil War (Blackmon 2009). County sheriffs exercised discretion over which arrests were made, which inmates were protected from the lynch mob, and which inmates were leased out to forced labor camps. Before sheriffs' offices became professional agencies in the image of modern police departments, sheriffs relied on local men to form posses in pursuit of escaped inmates, and to fortify the jail from vigilantes seeking mob violence (Kopel 2014).

\subsection{New states}

The abundance of counties, the newness of political communities, and the weakness of central parties contributed to the early adoption of elective sheriffs in the new states admitted between 1800 and 1824. States such as Indiana, Alabama, Mississippi, and Missouri lacked organized political parties, and sheriffs and other offices were elective in their first constitutions, which were considerably more liberal than the states with colonial legacies. Politics

in those states featured local, personalistic factions as well, and parties were slow to develop until the late Jacksonian period.

In contrast to the other newly-admitted states, Ohio and Louisiana represent two extreme cases with similar political environments. As part of the Northwest Territory, Ohio experienced strong partisan competition by 1802, when a Federalist territorial governor from New England riled Democratic-Republicans with unpopular patronage appointments. The Republicans outnumbered the sparse Federalists in the convention for the 1803 constitution, and succeeded in creating a strong county system with locally-elected officers. Since Republicans held a numeric advantage across the several dozen counties, they were assured patronage control and used the local sources of power to further organize partisans to secure statewide offices.

Louisiana was in extreme contrast, where the French Creole faction maintained hegemony in a highly undemocratic system with a strong governor. Ethnic cleavages dominated local 


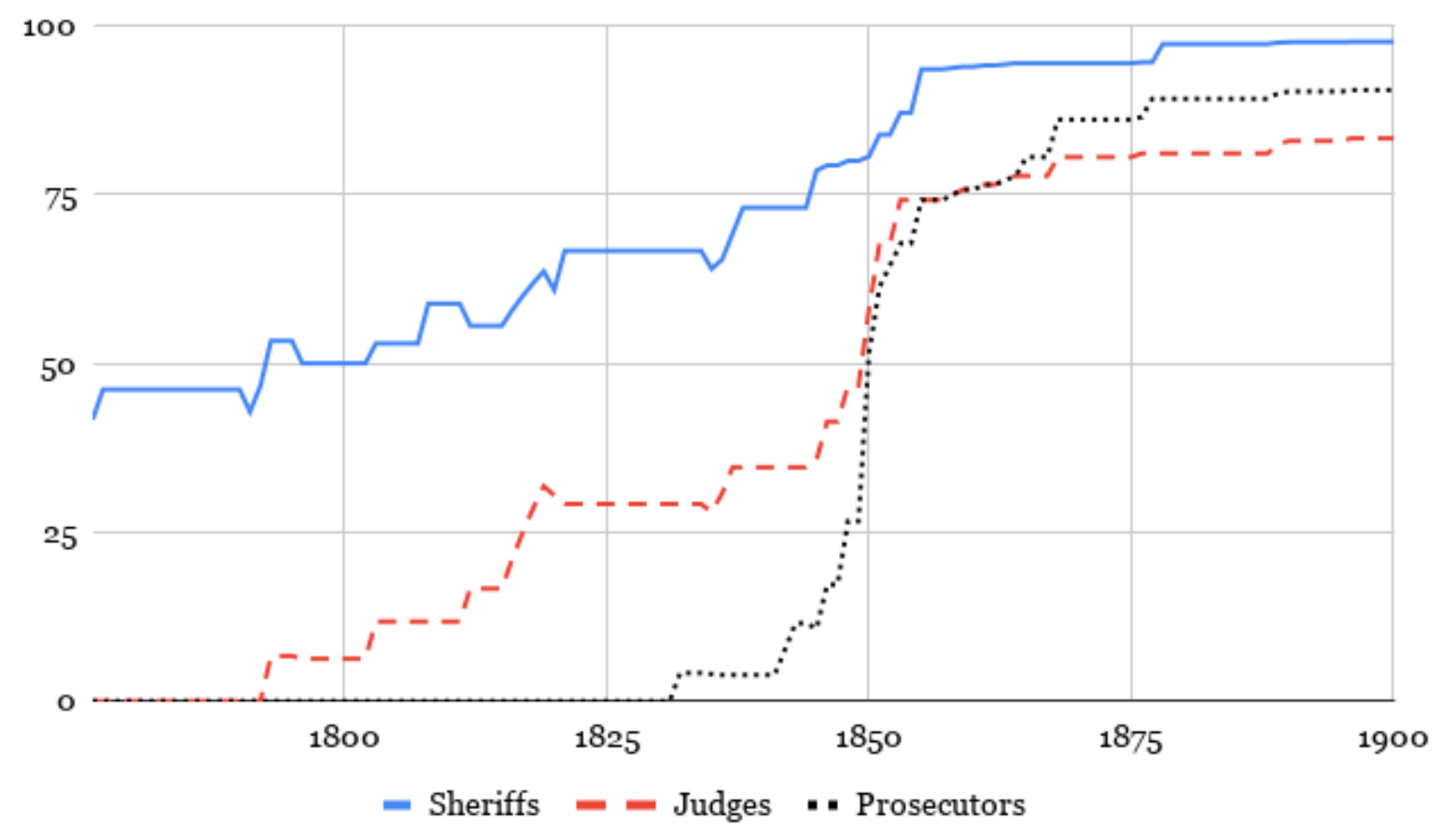

Figure 1: Percent of states with elected sheriffs, judges, and prosecutors (1776-1900)

political contests, and parties only weakly organized around national issues. By the 1830s, Whigs and Democrats were trading control of government and in 1845 the old system fell to a series of reforms to expand white suffrage and democratic elections in the parishes (the county-equivalent administrative unit in Louisiana).

\subsection{Comparing the timing of sheriffs' elections to other offices}

Given the important role that sheriffs play in the criminal justice system, and related policy arenas, it is worthwhile to compare them to other officers in that sphere. The extant literature on locally elective offices in the United States primarily focuses on two offices, prosecutors and judges (Ellis 2011, Shugerman 2010, Nelson 1993, Bandyopadhyay and McCannon 2014). The historical development of these two elected offices provides a helpful benchmark to contextualize the development of county sheriffs. 
Figure 1 shows the trends in the adoption of elected sheriffs, judges, and prosecutors. ${ }^{15}$ Sheriffs have always been, and are still today, the most widespread elected county office. In most states, sheriffs were made elective before either prosecutors or judges, often by several decades. In sixteen states, sheriffs were made elective before both judges and prosecutors. In sixteen other states, sheriffs were made elective at the same time as either judges or prosecutors. Two states, Maine and New Hampshire, started electing sheriffs after one of those two offices. Overall, 38 state elected sheriffs beginning at statehood or sooner (in the case of territories), nine states adopted sheriff elections after statehood, and three states never adopted them (Rhode Island, Alaska, and Hawaii). Just one state, Connecticut, has abandoned elected sheriffs in favor of appointments.

Political reformers between 1820 and 1860 prioritized expanding the franchise and increasing the number of offices within the reach of popular election (Ellis 2011, Tarr 2006). Reformers spent little time at conventions actually discussing the merits of making prosecutors elected, as was the case for the states that copied Pennsylvania's constitution in 1776 that included elected county sheriffs. Ellis (2011) argues that reformers were not seeking partisan advantage by making local office elective, because many of the reforms to subject prosecutors to elections came at a time when neither party held a clear electoral advantage. This reasoning is entirely consistent with the theory posited above, that elites in states with high party competition would seek to remove important offices like sheriffs from swings in party control of government.

Political elites will reform their political institutions in order to hedge against the risk of losing the statewide offices that distribute patronage. Since neither party was assured victory in the next statewide election, political elites faced an incentive to move local political offices within the reach of local voters. If the Whigs could not secure the governorship and the statewide patronage portfolio, including sheriff and prosecutor appointments, for example, they could at least minimize their losses by retaining control of the sheriffs in their local

\footnotetext{
${ }^{15}$ Table A.1 in the appendix provides the specific dates of these reforms in each state.
} 
strongholds.

\section{Sheriffs today: A movement away from elections?}

Three states never elected sheriffs: Rhode Island, Hawaii, and Alaska, as well as the District of Columbia and the five U.S. territories. A fourth state joins them today, Connecticut, after voters chose to make the office appointive in a 1999 referendum following decades of misconduct and abuse by officeholders. ${ }^{16}$ These cases are easy to explain in the context of local administration. Alaska is divided into boroughs that may or may not have a boroughwide government, and law enforcement has historically been provided by local departments and the state policy agency. In Hawaii, law enforcement is provided by county police departments, and although the state's "Sheriff Division" employs "sheriff's deputies", there are no elected sheriffs in the state. On the east coast, county government was never strong in New England, where politics was centered in towns, and the sheriffs in Rhode Island and Connecticut did not develop significant police and correctional powers.

The spread of elected sheriffs is not necessarily permanent, and the 20th and 21st century has seen a slight retrenchment of sheriffs' elections in several communities. Thirteen counties today no longer elect county sheriffs, and four counties have abandoned and readopted elected sheriffs. Table 2 lists the jurisdictions that do not elect a county sheriff, as well as the year of the reform that abolished sheriff elections (if relevant).

As of 2018, the total population of the four states and D.C., thirteen counties, and five territories that do not have elected sheriffs is over 24 million (approximately $7.4 \%$ of the U.S. population). ${ }^{17}$ On the other hand, nearly $93 \%$ of all Americans live in a county (or city) with an elected sheriff.

The same concerns that led Americans to adopt elected sheriffs in the past, including

\footnotetext{
${ }^{16}$ Prior to 2000, Connecticut sheriffs had limited responsibilities including serving writs, securing the courthouse, and executing search warrants. They fell under the civil-judicial model of sheriffs presented by Falcone and Wells (1995). In 1994, Iowa voters shot down a similar statewide referendum.

${ }^{17}$ The several counties that comprise New York City are the largest contributors to this sum, followed by Puerto Rico, which lacks counties.
} 
corruption and the centralization of power, have motivated some communities to begin appointing sheriffs in the 20th and 21st century. Urbanization played an important role in the movement away from sheriff elections, as illustrated by the case of New York City and a number of metropolitan cities in largely rural states (e.g. St. Louis, Denver, and Seattle). Many of the counties that appoint sheriffs are governed by home rule charters than allows the county executive or council to fill local offices by appointment rather than direct election. The several counties that comprise New York City are the largest contributors to this sum, followed by Puerto Rico, which lacks counties.

New York City's sheriff has been appointed by the mayor since 1942, when five counties merged offices and abolished their elective sheriffs. The sheriff in New York's Nassau County is appointed by the county executive, and Westchester County consolidated its sheriff's office and a municipal police department, replacing the sheriff with a Commissioner of Public Safety appointed by the county executive. Two counties in Colorado made similar decisions to consolidate police departments. Denver made its sheriff appointive in 1969 and moved much of the office's policing responsibilities to the city police department. In 2001, the City of Broomfield became the newest county in Colorado and merged its sheriff's office and municipal police department, led by an appointed police chief as ex-officio sheriff.

Voters in Riley County, Kansas approved a measure in 1973 to consolidate the county sheriff's office and two municipal police departments into a single county police department led by an appointed chief. A similar arrangement is found in St. Louis County, Missouri, where voters approved a new county charter in 1955 that made the sheriff appointed. A 2015 bill in the Missouri legislature proposed making the sheriff of the City of St. Louis appointive as well, following similar reforms to make other court officers appointed. ${ }^{18}$

Four counties in Oregon, Washington, and Florida have reformed their county sheriffs from elective to appointive and back to elective. Pierce County, Washington became the first county in the state to appoint their sheriff in 1980, after a series of scandals in county

\footnotetext{
${ }^{18}$ http://www.stltoday.com/news/local/govt-and-politics/mo-senate-bill-seeks-to-make-st-louis-sheriffan/article $43 f c 2432-7 d d 4-595 d-8024-611 d 4 f 87 d c b 1 . h t m l$
} 
Table 2: States and Counties That Do Not Elect Sheriffs

\begin{tabular}{ccc} 
State & County & Date \\
\hline Alaska & All 19 burroughs & - \\
Colorado & Broomfield City-County & 2001 \\
Colorado & Denver City-County & 1969 \\
Connecticut & All 8 counties & 2000 \\
Florida & Miami-Dade Co. & $1966-2018$ \\
Hawaii & All 5 counties & - \\
Kansas & Riley Co. & 1973 \\
Missouri & St. Louis Co. & 1955 \\
New York & New York Co. (Manhattan) & 1942 \\
New York & Kings Co. (Brooklyn) & 1942 \\
New York & Bronx Co. & 1942 \\
New York & Richmond Co. (Staten Island) & 1942 \\
New York & Queens Co. & 1942 \\
New York & Nassau Co. & 1938 \\
New York & Westchester Co. (Yonkers) & 1979 \\
Oregon & Multnomah Co. (Portland) & $1967-1978$ \\
Pennsylvania & Northampton Co. & 1978 \\
Pennsylvania & Luzerne Co. (Wilkes-Barre) & 2010 \\
Rhode Island & All 5 counties & - \\
Washington & King Co. (Seattle) & $1968-1996$ \\
Washington & Pierce Co. (Tacoma) & $1980-2006$ \\
\hline
\end{tabular}

Sheriffs are also absent in the District of Columbia, Puerto Rico, the U.S. Virgin Islands, American Samoa, Guam, and the Northern Mariana Islands.. 
government pushed voters to pass a new charter. A federal grand jury indicted the elected sheriff of Pierce County and several others on racketeering conspiracy charges in 1978. The new charter would allow the elected county executive and council to appoint the sheriff. Voters reinstated county elections in $2006 .^{19}$

Miami-Dade County in Florida reverted back to appointed sheriffs in the 1960s, and switched back to elections in 2019 (Hanks 2019). Voters approved a new home rule charter in 1957 that brought the county sheriff's office under the control of the metropolitan government, although the sheriff remained elected. In 1966, voters went back to the ballot box to make the sheriff appointed, and the incumbent sheriff was indicted on bribery charges later that year. A 2015 bill in the Florida legislature would have forced Miami-Dade County to reinstate its elective sheriff, along with seven other counties that have altered the elective status of their county officers. Ultimately, Miami-Dade county voters approved a 2018 ballot measure to reinstate sheriff elections (Hanks 2019).

Florida is the only state that elected sheriffs at statehood, abandoned elected sheriffs, and then readopted the institution again. Florida began electing their sheriffs in 1845, but discontinued the practice after the Civil War. When the Union military occupied the state, the Republican government appointed the sheriffs, including some counties' first and only African-American sheriffs. These appointed sheriffs were unpopular representatives of the Republican government and military occupation, and were subjected to popular dissent. When Reconstruction ended in 1877, many of the appointed sheriffs were run out of town as Republican support evaporated and by 1885 the state constitution reinstated county elections.

\footnotetext{
${ }^{19}$ The referendum passed 65.8 percent to 34.2 percent (Pierce County, Archived Elections, November 7, 2006. https://www.co.pierce.wa.us/337/Archived-Elections).
} 


\section{Sheriffs in an Era of Polarization}

"The irony of Mr. Sessions's nomination is that, if confirmed, he will be given a life tenure for doing with a federal prosecution what the local sheriffs accomplished twenty years ago with clubs and cattle prods."

Coretta Scott King in a letter to Congress (March 19, 1986)

When the U.S. Senate was considering the nomination of Jeff Sessions for the federal judiciary in 1986, civil rights leader Coretta Scott King wrote an incisive letter opposing an appointment that she believed would undo the work that she, her husband, and countless Americans had done for racial equality. Federal judges, of course, are not elected in the United States, but King referred to another political office that is elected and had obstructed racial justice in the South: county sheriffs. Senator Elizabeth Warren invoked King's words on the Senate floor during the hearing for Sessions's nomination as attorney general. ${ }^{20}$

The important role that county sheriffs play in American society, at the local and national levels, are in many ways illustrated by Coretta Scott King's quote on the impact that both sheriffs and federal judges can have on politics and policies. Today, reformers and social justice activists, including those affiliated with the Movement for Black Lives, have begun to take note of the role played by sheriffs in the criminal justice system. Given the context of elected sheriffs' state and the local origins laid in this paper, it is clear that sheriffs are relevant to politics and public policy up to the federal level. The defeat of 6-term Arizona sheriff Joe Arpaio, and his subsequent presidential pardon, illustrates the renewed interest that political actors are taking in this ancient but alive office (Davis and Haberman 2017). ${ }^{21}$

Perhaps no president in the modern era has wrapped their arms around county sheriffs as tightly as Donald Trump (Ulloa 2020). From his 2017 pardon of Joe Arpaio and public support for firebrand Milwaukee Sheriff David Clarke (Davis and Haberman 2017, Stevens

\footnotetext{
${ }^{20}$ For reading King's letter on the Senate floor, Warren drew the ire and condemnation of Senate Republicans, who formally admonished Warren for speaking ill of Sessions, who was still a sitting Senator and was protected by parliamentary rules of decorum. Majority Leader Mitch McConnell sparked a meme when he remarked, "She was warned. She was given an explanation. Nevertheless, she persisted."

${ }^{21}$ Comedian John Oliver addressed the topic of sheriffs' elections on a recent episode of his popular HBO show, Last Week Tonight (March 8, 2020).
} 
2017), to his partnership with local sheriffs to boost immigration enforcement, President Trump has not been shy about his affinity for county sheriffs. Several county sheriffs endorsed Trump in the 2016 presidential campaign and subsequently appeared alongside him in the White House. ${ }^{22}$

In a number of policy arenas, we observe national trends in how county sheriffs, especially those in rural counties, have responded to state-level policy changes. Examples of politicized and collectively organized sheriffs include the sheriffs in Colorado, New Mexico, and Virginia taking public stands against gun control laws, declaring their counties "Second Amendment Sanctuaries" (Goldstein 2019, Mascia 2020).

On the extreme end of the political spectrum, a growing movement of "constitutional sheriffs" highlights the office's roots to Norman and Anglo-Saxon tradition to argue that sheriffs' have supremacy over law enforcement within their county (Potok and Lenz 2016, Powers 2018, Goldstein 2019). Similar claims have been made by members of other anti-government groups, including Posse Comitatus, the Sovereign citizens, and various tax protesters (Kopel 2014). Recent research shows that a county sheriff's affiliation with the constitutional sheriff movement is associated with more violence against federal employees (Nemerever 2019). My findings in this paper demonstrate that these movements and their ideologies are based on a historical claim about elected sheriffs that is closer to myth than reality.

\section{Conclusion}

In this paper, I ask whether county sheriffs were directly elected from the beginning of the United States or if the institution was adopted more gradually. Based on newly-collected evidence from state constitutions and legislative records, I show that although half of the original colonies did elect sheriffs as early as 1776, the remaining colonies and several newlyadmitted states did not adopt sheriff elections for several decades. Contrary to the conven-

\footnotetext{
${ }^{22}$ In a 2017 White House event, President Trump joked with a Texas sheriff about targeting a state legislator who proposed reforming civil asset forfeiture laws (Nelson 2017).
} 
tional wisdom, I find that elected sheriffs were not adopted nationwide in one fell swoop during the Jacksonian Era, and that reformers in many states were conflicted over the best institutional arrangement for filling public offices like sheriff. Concerns about unconstrained executive power ruled the day and the vast majority of states elected sheriffs by the Civil War.

The historical timeline presented in this paper represents a more complicated story about the role of the independently elected county sheriff than the version presented by thenAttorney General Jeff Sessions, the National Sheriffs Association, and the "Constitutional" sheriffs movement. Americans in the past were divided about how to choose sheriffs, and states took different paths to arrive at the same institutional arrangement. Later on, more than a dozen communities decided to undo these reforms and appoint, or abolish, their sheriffs.

An important finding in this paper is that states and individual counties are able to decide whether or not they wish to continue electing their sheriffs. Despite the longevity and ubiquity of elected sheriffs, cases from New York to Miami to Seattle to Connecticut show that institutions are dynamic: the elected office of sheriff is not permanent or unchangeable. Future research should explore the persistent of the institution over time, as well as the reasons for why sheriffs were never elected in Hawaii, Alaska, Puerto Rico, and the other territories.

Political scientists do not yet know if sheriffs' elections deliver accountability to a greater degree than appointments. I have demonstrated the spread of elected sheriffs as an institution, and highlighted cases where communities decided to change their institutions. Although this paper presents evidence about the origins of elected sheriffs, the findings do not support a recommendation for continuing or discontinuing the practice. If any states or individual counties in the future decide to change their institutions, they should follow an evidence-based approach to policing and police accountability, and not feel beholden to sheriffs' elections for the sake of tradition. 


\section{Bibliography}

Bandyopadhyay, Siddhartha, and Bryan C. McCannon. "The Effect of the Election of Prosecutors on Criminal Trials." Public Choice 161.1-2 (2014): 141-156.

Bayley, David, and Philip C. Stenning. Governing the Police: Experience in Six Democracies. Routledge, 2017.

Berry, Christopher R., and Jacob E. Gersen. "Fiscal Consequences of Electoral Institutions." The Journal of Law and Economics 52.3 (2009): 469-495.

Besley, Timothy, and Stephen Coate. "Elected versus Appointed Regulators: Theory and Evidence." Journal of the European Economic Association 1.5 (2003): 1176-1206.

Blackmon, Douglas A. Slavery by Another Name: The Re-enslavement of Black Americans from the Civil War to World War II. Anchor, 2009.

Boyd, Julian P. "The Sheriff in Colonial North Carolina." The North Carolina Historical Review 5.2 (1928): 151-180.

Brooks, Connor. "Sheriffs' Offices, 2016: Personnel." Office of Justice Programs. Bureau of Justice Statistics, Oct 2019.

Brown, Lee. "The Role of the Sheriff." The Future of Policing 9 (1978).

Carpenter, David A. "The Decline of the Curial Sheriff in England 1194 - 1258." The English Historical Review 91.CCCLVIII (1976): 1-32.

Chand, Daniel E. "Is it Population or Personnel? The Effects of Diversity on Immigration Policy Implementation by Sheriff Offices." Public Performance \& Management Review (2019): 1-30.

Corvalan, Alejandro, Pablo Querubin, and Sergio Vicente. "The Political Class and Redistributive Policies." Journal of the European Economic Association (2016). 
Davis, Julie Hirschfeld, and Maggie Haberman. "Trump Pardons Joe Arpaio, Who Became Face of Crackdown on Illegal Immigration." The New York Times. Aug 25, 2017.

De Krey, Gary S. "Political radicalism in London after the Glorious Revolution." The Journal of Modern History 55.4 (1983): 585-617.

Ellis, Michael J. "The Origins of the Elected Prosecutor." Yale Law Journal 121 (2011): 1528.

Falcone, David N., and L. Edward Wells. "The County Sheriff as a Distinctive Policing Modality." American Journal of Police 14.3/4 (1995): 123-149.

Farris, Emily M., and Mirya R. Holman. "Public Officials and a 'Private' Matter: Attitudes and Policies in the County Sheriff Office Regarding Violence Against Women." Social Science Quarterly 96.4 (2015): 1117-1135.

Farris, Emily M., and Mirya R. Holman. "All Politics is Local? County Sheriffs and Localized Policies of Immigration Enforcement." Political Research Quarterly 70.1 (2017): 142-154.

Frum, David. "The Anti-Trump Recoil Goes Too Far." The Atlantic, February 14, 2018.

Gailmard, Sean. "Building a new imperial state: The strategic foundations of separation of powers in America." American Political Science Review 111.4 (2017): 668-685.

Gailmard, Sean. "Imperial Politics, English Law, and the Strategic Foundations of Constitutional Review in America." American Political Science Review 113.3 (2019): 778-795.

Gilbertson, Henry Stimson. The County: The 'Dark Continent' of the American Politics. National Short Ballot Organization, 1917.

Goldstein, Jared A. "A Group of Sheriffs Is Refusing to Enforce Gun Laws Based on a 1960s Constitutional Theory From the KKK." Slate. March 20, 2019. 
Gorski, Richard. The Fourteenth-Century Sheriff: English Local Administration in the Late Middle Ages. Boydell Press, 2003.

Greenblatt, Alan. "Why there are so many bad sheriffs" Governing, Apr. 2018.

Gurman, Sadie. "Why some voters are angry over Sessions' 'Anglo-American heritage' comments." PBS NewsHour, Feb. 13, 2018.

Hanks, Douglas. "Would a Democrat or Republican make a better Miami-Dade sheriff? It might not matter." Miami Herald, March 5, 2019.

Henderson, Thomas A. "The Relative Effects of Community Complexity and of Sheriffs upon the Professionalism of Sheriff Departments." American Journal of Political Science (1975): 107-132.

Huber, Gregory, and Sanford C. Gordon. "Accountability and coercion: Is justice blind when it runs for office?." American Journal of Political Science 48.2 (2004): 247-263.

Jefferson, Thomas. "Letter to Samuel Kercheval, July 12, 1816." The works of Thomas Jefferson 12 (1999).

Kimball, David C., and Martha Kropf. "The Street-Level Bureaucrats of Elections: Selection Methods for Local Election Officials." Review of Policy Research 23.6 (2006): 1257-1268.

Kopel, David B. "The Posse Comitatus and the Office of Sheriff: Armed Citizens Summoned to the Aid of Law Enforcement." Journal of Criminal Law \& Criminology 104 (2014): 761.

Kopel, David B. "The Anglo-American Office of Sheriff". The Volokh Conspiracy, Reason Magazine, 2018.

Lerman, Amy E., and Vesla M. Weaver. Arresting Citizenship: The Democratic Consequences of American Crime Control. University of Chicago Press, 2014.

Magary, Drew. "The Case Against Sheriffs". GQ. Feb 16, 2018. 
Mascia, Jennifer. "Second Amendment Sanctuaries, Explained." The Trace. January 14, 2020.

McCormick, Richard Patrick. The Second American Party System: Party Formation in the Jacksonian Era. Chapel Hill, University of North Carolina Press, 1966.

Mickey, Robert. Paths Out of Dixie: The Democratization of Authoritarian Enclaves in America's Deep South, 1944-1972. Vol. 147. Princeton University Press, 2015.

Moley, Raymond. "The Sheriff and the Constable." The ANNALS of the American Academy of Political and Social Science 146.1 (1929): 28-33.

Mondschein, Ken. "The Medieval Problem with 'Anglo-American' Sheriffs." The Public Medievalist, blog. 2018.

Monet, Jenni. "Sheriffs refuse to send troops to Standing Rock as public outrage and costs mount." Yes! Magazine. Nov, 2016.

Moore, Toby. "Race and the County Sheriff in the American South." International Social Science Review 72.1/2 (1997): 50-61.

Morris, William Alfred. The Medieval English Sheriff to 1300. No. 96. Manchester University Press, 1927.

National Sheriffs' Association. "National Sheriffs' Association Ongoing Support Of the Right to Elect the Office of Sheriff." Resolution No. 1, 2016

National Sheriffs' Association. "National Sheriffs' Association Acknowledges The Elected Office Of Sheriff As the Chief Local Law Enforcement Office Throughout Our Nation.” Resolution No. 1, 2017

National Sheriffs' Association. "National Sheriffs' Association Supports The Elected Office of the Sheriff." Resolution No. 4, 2019 
Nelson, Caleb. "A Re-Evaluation of Scholarly Explanations for the Rise of the Elective Judiciary in Antebellum America." The American Journal of Legal History 37.2 (1993): $190-224$.

Nelson, Louis. "Trump invites sheriff to 'destroy' Texas state lawmaker who opposes asset forfeiture." Politico. Feb. 07, 2017.

Nemerever, Zoe. "Contentious Federalism: Sheriffs, State Legislatures, and Political Violence in the American West." Political Behavior (2019): 1-24.

Neuhauser, Alan. "Running for a badge: Why does the U.S. still elect sheriffs?" U.S. News and World Report. Nov. 4, 2016.

Partridge, Mark, and Tim R. Sass. "The productivity of elected and appointed officials: the case of school superintendents." Public Choice 149.1-2 (2011): 133.

Potok, Mark, and Ryan Lenz. "Line in the Sand." Intelligence Report, Southern Poverty Law Center. June 13, 2016.

Powers, Ashley. "The Renegade Sheriffs". Annals of Law Enforcement, The New Yorker. April 30, 2018.

Reaves, Brian A., and Matthew J. Hickman. Census of State and Local Law Enforcement Agencies, 2008. US Department of Justice, Office of Justice Programs, 1998.

San Antonio Express-News Editorial Board, "Office of Constable No Longer Needed." San Antonio Express-News, 2019

Sances, Michael W. "The Distributional Impact of Greater Responsiveness: Evidence from New York Towns." The Journal of Politics 78.1 (2016): 105-119.

Scott, Roger. "Roots: A Historical Perspective of the Office of Sheriff." National Sheriffs' Association, 2011. 
Sheets, Connor. "Wasted Funds, Destroyed Property: How Sheriffs Undermined Their Successors After Losing Reelection". Pro Publica, June 2019.

Shugerman, Jed Handelsman. "Economic Crisis and the Rise of Judicial Elections and Judicial Review." Harvard Law Review (2010): 1061-1150.

Signorini, Renatta. "State Constable Role in Commonwealth Debated", Pittsburgh TribuneReview, 2019.

Skowronek, Stephen. Building a New American State: The Expansion of National Administrative Capacities, 1877-1920. Cambridge University Press, 1982.

Solanga, Robert. "Santa Clara Sheriff's gun-permit process: public safety or politics?" The Mercury News. Nov. 24, 2019.

Stevens, Matt. "David Clarke, Milwaukee County sheriff and Trump supporter, resigns." The New York Times. Aug 31, 2017.

Tarr, G. Alan. Understanding State Constitutions. Princeton University Press, 2000.

Thompson, Daniel M. "How Partisan is Local Law Enforcement? Evidence from Sheriff Cooperation with Immigration Authorities." American Political Science Review 114.1 (2020a): 222-236.

Thompson, Daniel M. "Do Elections Increase Local Policy Responsiveness? Evidence from Elected Police Commissioners". Working Paper, 2020b.

Tomberlin, James. "Don't Elect Me: Sheriffs and the Need for Reform in County Law Enforcement." Virginia Law Review 104 (2018): 113.

Ulloa, Jazmine. "All the president's sheriffs: How one law enforcement group became ardent Trump supporters". The Boston Globe. Jan 20, 2020. 
U.S. Census, Bureau of the. 1992 Census of Governments. Vol. 1: Government Organization, No. 2: Popularly Elected Officials. Washington, D.C., 1992.

Watson, Alan D. "The Appointment of Sheriffs in Colonial North Carolina: A Reexamination." The North Carolina Historical Review 53.4 (1976): 385-398.

Watson, Alan D. "County Fiscal Policy In Colonial North Carolina." The North Carolina Historical Review 55.3 (1978): 284-305.

Whalley, Alexander. "Elected versus appointed policy makers: Evidence from city treasurers." The Journal of Law and Economics 56.1 (2013): 39-81.

White, Ariel. "Misdemeanor Disenfranchisement? The Demobilizing Effects of Brief Jail Spells on Potential Voters." American Political Science Review 113.2 (2019): 311-324.

Wilson, Beth. "49ers loom large in election of Santa Clara's Police Chief". KQED, 2016.

Zoorob, Michael. "There's (Rarely) a New Sheriff in Town: The Incumbency Advantage for County Sheriffs." Working paper, 2019a.

Zoorob, Michael. "Going National: Immigration Enforcement and the Politicization of Local Police." Working paper, 2019b.

\section{Appendix}


Table A.1: Timing of State Reforms for Direct Elections of Sheriffs, Judges, and Prosecutors

\begin{tabular}{|c|c|c|c|}
\hline State & Sheriffs & Judges & Prosecutors \\
\hline Pennsylvania & 1706 & 1848 & 1850 \\
\hline Delaware & 1706 & - & - \\
\hline New Jersey & 1776 & - & - \\
\hline Maryland & 1776 & 1851 & 1851 \\
\hline North Carolina & 1776 & 1868 & 1868 \\
\hline Georgia & 1777 & 1812 & 1855 \\
\hline Kentucky & 1792 & 1850 & 1850 \\
\hline Vermont & 1793 & 1793 & 1850 \\
\hline Ohio & 1802 & 1802 & 1850 \\
\hline South Carolina & 1808 & - & 1868 \\
\hline Indiana & 1816 & 1816 & 1843 \\
\hline Mississippi & 1817 & 1817 & 1832 \\
\hline Illinois & 1818 & 1818 & 1848 \\
\hline Alabama & 1819 & 1819 & 1850 \\
\hline Missouri & 1821 & 1851 & 1851 \\
\hline New York & 1821 & 1846 & 1846 \\
\hline Arkansas & 1829 & 1836 & 1848 \\
\hline Michigan & 1837 & 1837 & 1850 \\
\hline Tennessee & 1835 & 1853 & 1853 \\
\hline Connecticut & 1838 & 1850 & - \\
\hline Florida & 1845 & 1853 & 1865 \\
\hline Louisiana & 1845 & 1845 & 1852 \\
\hline Texas & 1845 & 1850 & 1850 \\
\hline Iowa & 1846 & 1846 & 1846 \\
\hline Wisconsin & 1848 & 1848 & 1848 \\
\hline California & 1850 & 1850 & 1850 \\
\hline Minnesota & 1851 & 1858 & 1858 \\
\hline Virginia & 1851 & 1851 & 1851 \\
\hline Massachusetts & 1855 & - & 1855 \\
\hline Maine & 1855 & - & 1842 \\
\hline Oregon & 1859 & 1859 & 1859 \\
\hline Kansas & 1861 & 1861 & 1857 \\
\hline West Virginia & 1861 & 1861 & 1861 \\
\hline New Hampshire & 1878 & - & 1877 \\
\hline Rhode Island & - & - & - \\
\hline
\end{tabular}

States are ordered by the year in which they adopted direct elections for county sheriffs. The original thirteen colonies are in bold. Data for judicial elections from Shugerman (2010). Data for prosecutor elections from Ellis (2011). 